\title{
PETROGENESIS OF HOMRAT EL-GIRIGAB ALKALI-FELDSPAR GRANITES, NORTHERN EASTERN DESERT, EGYPT
}

\author{
Waheed Elwan \\ Geology Department, Faculty of Science, Zagazig University, Zagazig- 44519, Sharkia Egypt. \\ E-mail: wibraheem@hotmail.com
}

\begin{abstract}
Homrat El-Girigab area located at Northern Eastern Desert which, characterized by abundant intrusion of calc-alkaline and alkaline/peralkaline granitoids and their associated volcanics. These granitoids have a particular geodynamic interest as they provide an outstanding opportunity to tell how continental crust of ANS was formed. Homrat El-Girigab area is covered by Dokhan volcanics (andesite \& dacites), which intruded by alkali-feldspar granites. The chemistry of biotites indicates that, the alkali-feldspar granites were crystallized from alkaline crustal source under oxidized conditions (i.e. nickel-nickel oxide buffer or $\mathrm{NNO}$ ). They were crystallized under conditions including, temperatures range from 700 to $750{ }^{\circ} \mathrm{C}$, pressures 3 to $4 \mathrm{kbar}$, depths of emplacement range from 7 to $11 \mathrm{~km}$ and under Oxygen fugacity $\left(\log f \mathrm{f}_{2}\right)$ ranges from -15 to -16 . Homrat El-Girigab alkali-feldspar granites (HGAFGs) are alkaline, ferroan anorogenic (i.e. extensional) A-type granites. They were emplaced during the late post-collisional crustal extensional stage at which the effect of lithospheric delamination, and thus asthenospheric uprise, likely diminishes. At this stage the mantle-derived mafic melts start intraplating the lower crustal levels, that facilitated by the abundance of strike-slip faults and shear zones. This lithospheric intraplating caused widespread melting producing the alkaline magma of HGAFGs. The studied granites were derived from lower crustal amphibolitic source and evolved mainly by fractional crystallization.
\end{abstract}

Keywords: Homrat El-Girigab, Eastern Desert, Mineral chemistry, Petrogenesis

\section{INTRODUCTION}

The Arabian Nubian Shield (ANS), represents the biggest Neoproterozoic juvenile continental crust belt on Earth. The evolution ANS juvenile crust includes three subsequent stages: 1$)$ subduction ( $~ 870-$ $670 \mathrm{Ma}$ ), including the formation of island arc volcano-sedimentary sequences, plutonic rocks and amalgamation of these accreted terrains onto East Gondwana continental block (Abdelsalam \& Stern, 1996; Condie et al., 2009); 2) continental collisional (650-640 Ma) between the juvenile accreted ANS crust with pre-Neoproterozoic continental blocks of West Gondwana (Abdelsalam et al., 2002), which characterized by formation of calc-alkaline gabbros and granodiorites; 3 ) late to post-collisional (590-550 $\mathrm{Ma}$ ), which follow collision involving extensional collapse of the thickened lithosphere (Avigad et al., 2005; El-Bialy, 2010; Eyal et al., 2010; Be'eri-Shlevin et al., 2011), including formation of volcanics and calc-alkaline to alkaline/peralkaline granitic rocks.

The Egyptian granitoids were classified into: 1) older, syn-orogenic calc-alkaline, I-type granitoids (880-610 Ma), which related to the end of Pan-African orogeny; 2) younger post-orogenic either not strictly anorogenic, calc-alkaline/alkaline granitoids (640-610 Ma) or alkaline/peralkaline, true anorogenic A-type granites (600-550 Ma). The later are related to rifting (Bielski et al., 1979; Moghazi, 1999, Azer, 2013). Different models have been proposed for the sources of the post-collisional A-type granites in ANS, which invoke contrasting continental crust and mantle reservoirs (Ali et al., 2009, 2014; Be'eriShlevin et al., 2009, 2010; El-Bialy \& Hassen, 2012; Eyal et al., 2010; Farahat \& Azer, 2011; Moghazi et al., 2011, 2012).

Homrat El-Girigab is located at northern Eastern Desert terrain, which characterized by abundant intrusion of calc-alkaline and alkaline/peralkaline granitoids and their associated volcanics, constituting 
Elwan, W.

$\sim 80 \%$ of the basement outcrops, therefore, these granitoids have a particular geodynamic interest as they provides an outstanding opportunity to tell how continental crust forms. In addition, some of late to postcollisional A-type granite plutons in ANS are considered specialized granites (Drysdall et al., 1984; Küster, 2009; Johnson et al., 2011). A-type granites in ANS received much attention due the potential economic significance of their elevated abundances of REE, U, Th, Ta and Nb. Homrat El-Girigab area got more attention due to the high radioactivity of both its uraniferrous granite and the stream sediment along the main Wadi (Salman et al., 1995; Abd El-Ghafour et al., 2001). Furthermore, the granitic rocks in the area are mined for feldspar at latitude $27^{\circ} 45^{\circ} 30^{\prime \prime}$ and longitude $33^{\circ} 18^{\prime} 20^{\prime \prime}$ as raw material for ceramic industry. Wetait et al. (2014) described the granitic rocks in Homrat El-Girigab as calc-alkaline Itype granites, which were derived in a post-orogenic tectonic environment.

The aim of the present work is to detect the petrogenesis of the Homrat El-Girigab alkali-feldspar granites through their mineralogical and geochemical characteristics.

\section{GEOLOGIC SETTING}

Homrat El-Girigab area located in the northern part of Esh El-Mallaha range, Northern Eastern Desert. The area lies about $70 \mathrm{~km}$ to southeast of Ras Ghareb city, $15 \mathrm{~km}$ to southwest of Cairo- Hurghada Road. It is located between latitude $27^{\circ} 44^{`} 27^{\prime \prime}-27^{\circ} 47^{`} 15 \mathrm{~N}$ and longitude $33^{\circ} 16^{\prime} 55.33^{\prime \prime}-33^{\circ} 19^{`} 56.55 \mathrm{E}$. Homrat El-Girigab area is covered by moderate relief peaks of Dokhan volcanics (DVs), which are intruded by high relief hills of alkali-feldspar granites (Fig. 1\& Fig. 2a). Dokhan volcanics are hard, massive and non-foliated rocks. They show grey, greenish grey to dark black colors and they are represented by andesite and dacites varities.

Fig.1: Geological map of Homrat El-Girigab area.

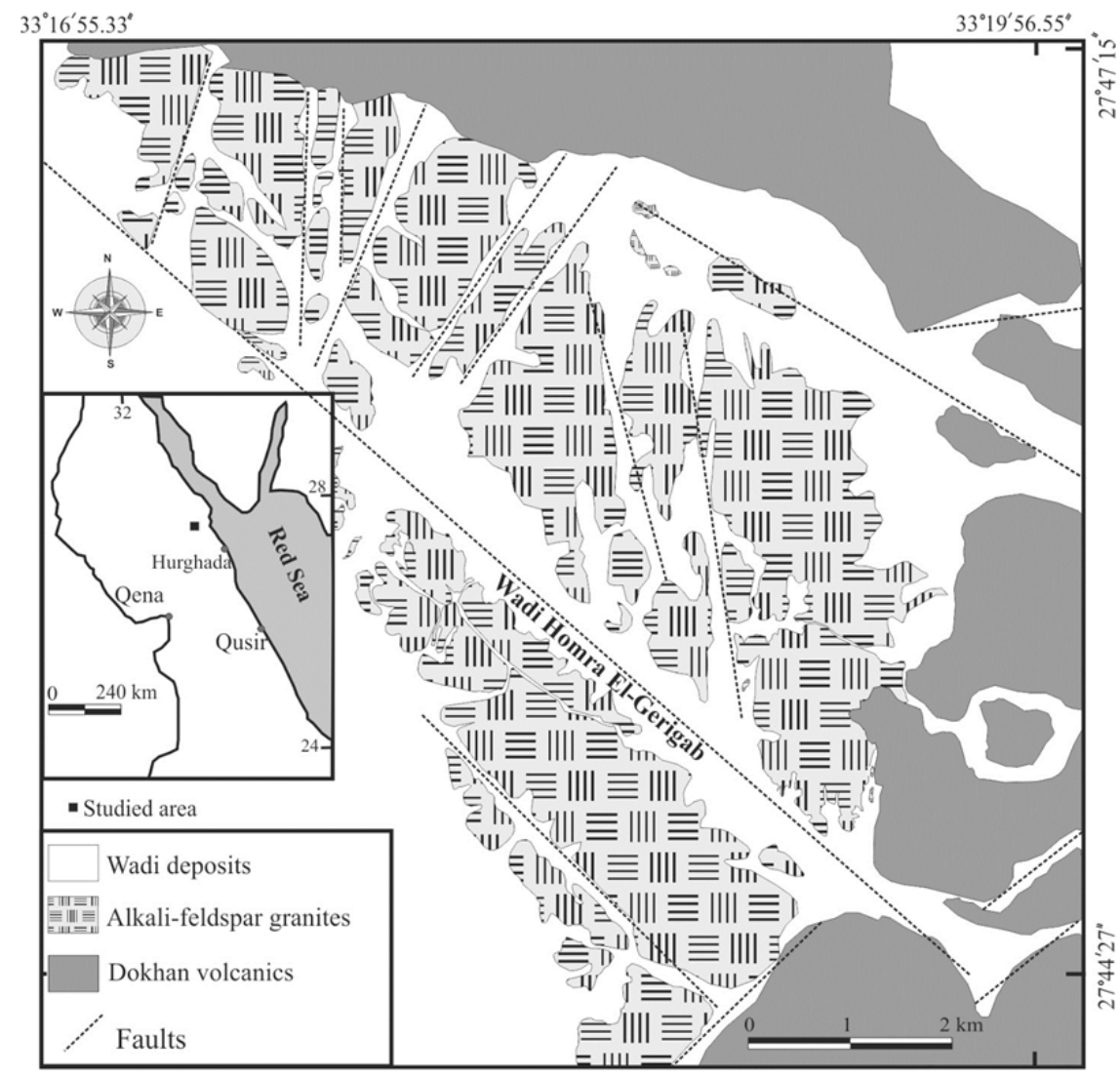

HGAFGs peaks are surrounded by Dokhan volcanic hills. They are hard massive with reddish pink to red color, locally weathered, well jointed and show exfoliation joints (Fig. 2b). HGAFGs are dissected by acidic dykes (i.e. felsite and porphyritic rhyolite). These granitic rocks contain sub-rounded xenoliths of Dokhan volcanics. The area is dissected by major faults trending NW-SE and NE-SW and subordinate NNW-SSE and E-W trends. 

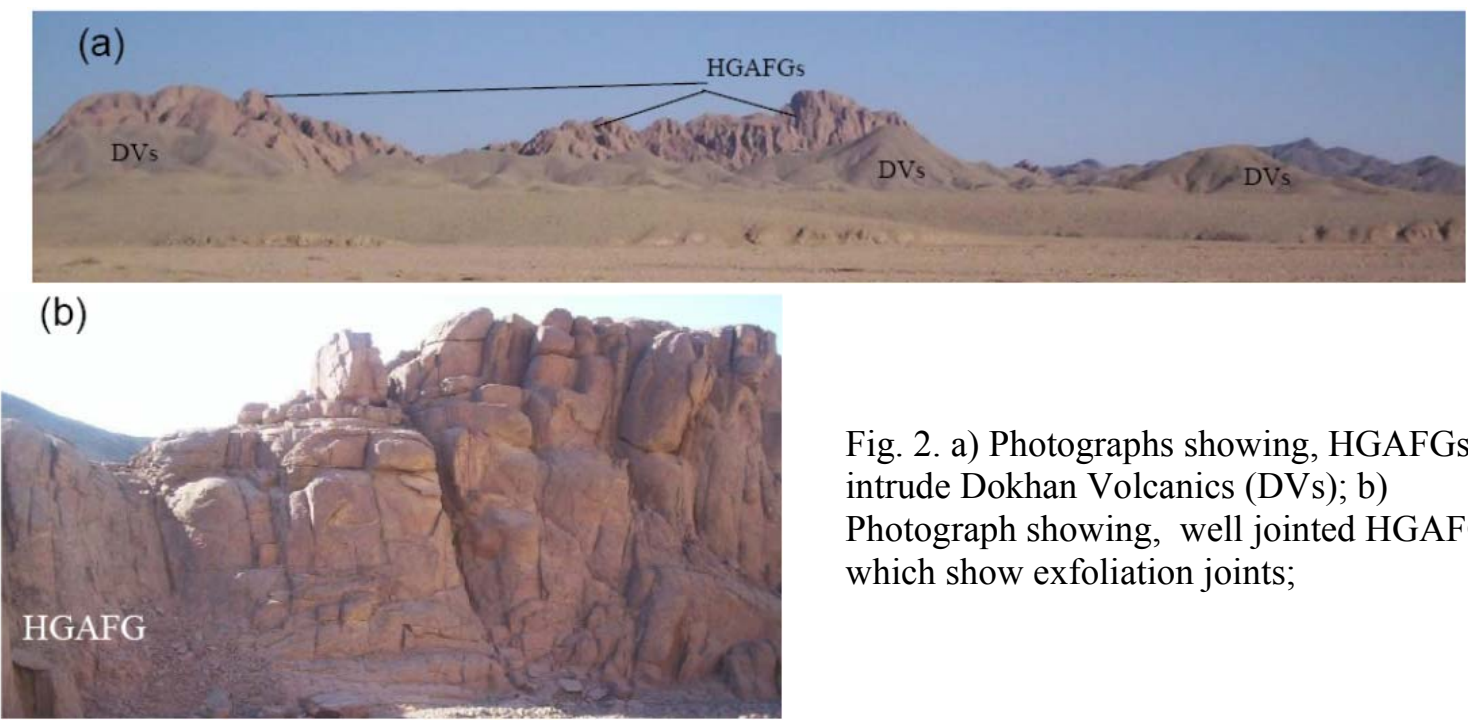

Fig. 2. a) Photographs showing, HGAFGs intrude Dokhan Volcanics (DVs); b) Photograph showing, well jointed HGAFGs, which show exfoliation joints;

\section{PETROGRAPHY}

HGAFGs are medium to coarse-grained hypidiomorphic rocks, being composed mainly of K-feldspar, quartz, plagioclase with subordinate amount of biotite. The accessory minerals are sphene, zircon, apatite, allanite and fluorite, while the secondary minerals are kaolinite, sericite and chlorite. The rock shows porphyritic, rapakivi and granophyric textures.

K-feldspars are represented by subhedral crystals of orthoclase-perthite and microcline. Some perthite crystals are mantled by oligoclase forming rapakivi texture (Fig. 3a). Quartz occurs as subhedral to anhedral crystals, which invade with reaction rim along their contacts. Granophyric intergrowth between $\mathrm{K}$-feldspar and quartz is common (Fig. 3b). Plagioclase occurs either as medium to coarse subhedral tabular crystals. Plagioclase crystals are corroded and enclosed ophitically by other mineral constituents. Biotite occurs as subhedral to anhedral flacks (Fig. 3c), which are partly altered to chlorite. Sphene occurs as subhedral crystals filling the interstices between quartz and feldspar (Fig. 3d. Zircon occurs as subhedral to euhedral crystals which associated with apatite and allanite (Fig. 3e). Apatite form colorless euhedral prismatic crystals. Allanite occurs as subhedral crystals which are sending anastomosing cracks along its surrounding minerals. Fluorite occurs as subhedral to anhedral grains associated with biotite (Fig. $3 \mathrm{e})$.

\section{Analytical techniques}

A total of 7 spots in biotite from alkali-feldspar granites were analyzed by microprobe analyses (Table 1). The microprobe analyses were carried out using Cameca SX-100 Electron probe Microanalyzer, at Department of Electron Microanalysis, Geological Institute of Dionyz Stür, Bratislava, Slovak Republic. The microprobe was operated at an acceleration voltage of $15 \mathrm{kv}$, beam current of $20 \mathrm{nA}$, electron beam diameter of $5 \mu \mathrm{m}$ and using ZAF corrections. The chemical analyses of 6 fresh representative samples from HGAFGs (Table 2) were carried out using Panalytical Axios Advanced X-ray fluorescence (XRF). The analytical precision is $2-5 \%$. The chemical analyses were carried out at Central Metallurgical Research and Development Institute (CMRDI), El-Tebbin, Helwan, Egypt.

\section{Mineral chemistry}

The analyzed biotites show a limited variation in composition and comparable contents of $\mathrm{Al}_{2} \mathrm{O}_{3}, \mathrm{TiO}_{2}$, $\mathrm{FeO}$ and $\mathrm{MgO}$ (Table 1). Fluorine content ranges from 0.44 to 1.86 (Table 1). According to $\mathrm{FeO}+\mathrm{MnO}$ $10 * \mathrm{TiO}_{2}-\mathrm{MgO}$ ternary diagram (Nachit et al., 2005) the studied trioctahedral micas are of primary magmatic origin (Fig. 4a). By using $\mathrm{Al}^{t}-\mathrm{Fe}^{2+} /\left(\mathrm{Fe}^{2+}+\mathrm{Mg}\right.$ ) binary diagram (Rieder et al., 1999), the studied micas were classified as biotite (Fig. 4b). 


\section{Elwan, W.}

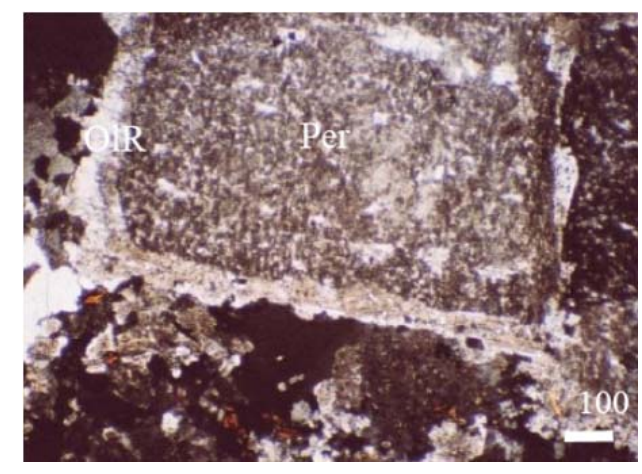

a

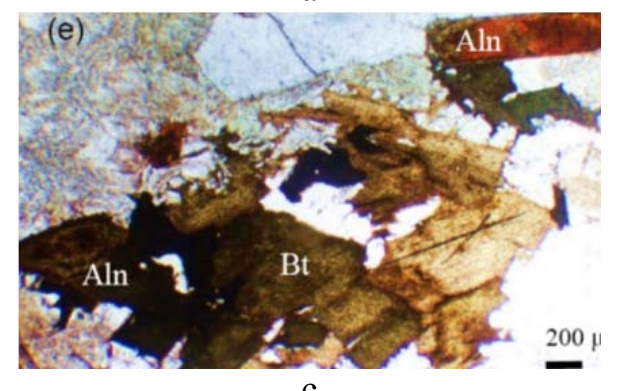

$\mathrm{C}$

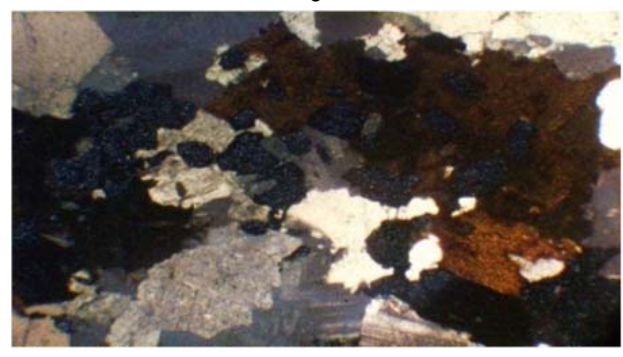

e
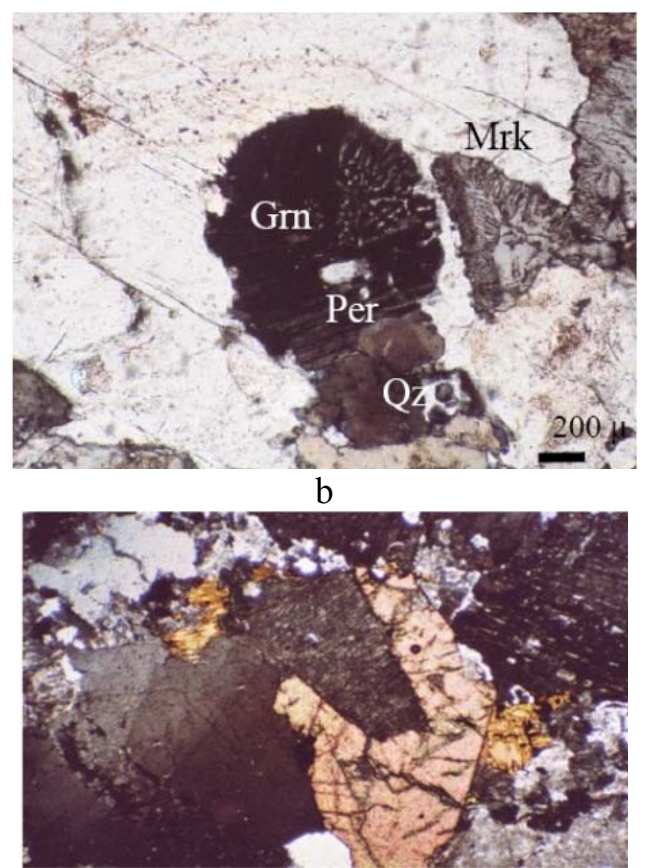

d

Fig. 3 a-e): Photomicrographs of HGAFGs showing a) perthite phenocryst (Per) surrounded by oligoclase rim $(\mathrm{OIR})$, forming rapakivi texture, $\mathrm{CN}$; b) Granophyric intergrowth (Grn) between perthite (per) and quartz, CN; c) Subhedral biotite (Bt) and allanite (Alt) crystals, PPL; d) Subhedral sphene (Sph) filling the interstices between perthite and quartz, CN; e) Biotite crystals (Bt), which associated with subhedral to anhedral fluorite grains (Flu), $\mathrm{CN}$.

As aluminum play an important role in the alkalinity of the magma and could be used as a factor controlling alkalinity, acidity and as an indicator for pressure prevailing during the process of crystallization, thus the biotite composition could be used to detect the nature of magmatic source. On Mg- $\mathrm{Al}^{\mathrm{t}}$ binary diagram (Nachit et al., 1985), the biotite in HGAFGs implies crystallization from an alkaline magma (Fig. 3c). $\mathrm{Fe}^{2+} /\left(\mathrm{Fe}^{2++} \mathrm{Fe}^{3+}\right)$ ratios range from 0.86 to 0.90 (Table 1). Furthermore, the analyzed biotite samples were clustered around nickel-nickel oxide (NNO) buffer in $\mathrm{Fe}^{2+}-\mathrm{Fe}^{3+}-\mathrm{Mg}$ ternary diagram (Wones \& Eugester, 1965), which suggest a moderate oxidation conditions (Fig. 4d). The calculated Oxygen fugacity buffers $\left(\log \mathrm{fO}_{2}\right)$ of the studied biotite range from -14.92 to -16.28 according to the equilibrium equation of Huebner \& Sato (1970) (Table 1). By using the calculated Oxygen fugacity buffer and the $\mathrm{Fe}^{2+} /\left(\mathrm{Fe}^{2+}+\mathrm{Fe}^{3+*} 100\right)$ ratio the biotite analyses were plotted on $\mathrm{T}^{\circ} \mathrm{C}$ - $\log \mathrm{fO}_{2}$ diagram (Wones \& Eugester, op. cit.). The studied biotites follow the oxidizing trend (Fig. 4e), which represent the undersaturated conditions during the crystallization of biotites from the melt (Wones \& Eugester, 1965). The temperatures of crystallization that calculated from the chemistry of biotites range from 700 to 750 .

\section{GEOCHEMISTRY}

\section{Major and trace element}

As shown in Table (2), HGAFGs have limited compositional variation, exhibiting narrow ranges of $\mathrm{SiO}_{2}$ (70.01- 72.91 wt. \%), $\mathrm{Al}_{2} \mathrm{O}_{3}$ (13.68- 14.25 wt. \%), $\mathrm{CaO}\left(0.66-0.96\right.$ wt. \%) and $\mathrm{TiO}_{2}$ contents $(0.11-$ 0.23 wt. \%). They are rich in alkalis $\left(\mathrm{Na}_{2} \mathrm{O}+\mathrm{K}_{2} \mathrm{O}\right),(10.67-11.41$ wt. \%) and depleted in $\mathrm{MgO}(0.13-0.31$ wt. \%). The enrichment of $\mathrm{Fe}_{2} \mathrm{O}_{3}{ }^{\mathrm{t}}$ relative to $\mathrm{MgO}$ indicates A-type signature (Frost et al., 2001). The presence of sodium metasilicates (NS $=1$, on average; Table 2) in the CIPW normative values is a characteristic feature of peralkaline rocks. 
Petrogenesis of Homrat El-Girigab alkali-feldspar granites

Table 1. Microprobe analyses (wt. \%) of and structural formula (apfu) biotite in HGAFGs

\begin{tabular}{|c|c|c|c|c|c|c|c|}
\hline Sample & \multicolumn{3}{|c|}{21} & \multicolumn{2}{|c|}{33} & \multicolumn{2}{|c|}{18} \\
\hline Oxides & 1 & 2 & 3 & 1 & 2 & 1 & 2 \\
\hline $\mathrm{SiO}_{2}$ & 36.13 & 35.72 & 35.52 & 35.77 & 35.77 & 35.83 & 35.51 \\
\hline $\mathrm{TiO}_{2}$ & 3.54 & 3.36 & 3.12 & 3.08 & 3.08 & 2.95 & 3.76 \\
\hline $\mathrm{Al}_{2} \mathrm{O}_{3}$ & 11.42 & 11.26 & 11.42 & 11.22 & 13.31 & 13.23 & 13.47 \\
\hline $\mathrm{FeO}$ & 27.54 & 28.89 & 29.66 & 29.08 & 29.48 & 29.53 & 28.76 \\
\hline $\mathrm{MgO}$ & 5.57 & 5.18 & 5.44 & 5.52 & 2.59 & 2.43 & 2.56 \\
\hline $\mathrm{MnO}$ & 0.58 & 0.53 & 0.40 & 0.42 & 0.49 & 0.50 & 0.45 \\
\hline $\mathrm{CaO}$ & 0.02 & 0.01 & 0.01 & 0.00 & 0.03 & 0.01 & 0.05 \\
\hline $\mathrm{Na}_{2} \mathrm{O}$ & 0.03 & 0.03 & 0.13 & 0.10 & 0.11 & 0.10 & 0.16 \\
\hline $\mathrm{K}_{2} \mathrm{O}$ & 8.79 & 8.99 & 8.44 & 8.61 & 8.92 & 8.92 & 8.84 \\
\hline $\mathrm{F}$ & 1.13 & 1.10 & 0.97 & 0.44 & 1.29 & 1.86 & 1.52 \\
\hline$\overline{\mathrm{Cl}}$ & 0.37 & 0.42 & 0.41 & 0.42 & 0.47 & 0.47 & 0.52 \\
\hline $\mathrm{H}_{2} \mathrm{O}$ & 1.45 & 1.51 & 1.48 & 1.68 & 1.46 & 1.24 & 1.39 \\
\hline Total & 96.17 & 96.44 & 96.21 & 96.05 & 96.34 & 95.97 & 96.24 \\
\hline \multicolumn{8}{|c|}{ Structural Formula based on 22 Oxygen atoms } \\
\hline $\mathrm{Si}$ & 6.02 & 5.88 & 5.88 & 5.84 & 5.89 & 6.09 & 5.86 \\
\hline $\mathrm{Al}(\mathrm{IV})$ & 1.98 & 2.12 & 2.12 & 2.16 & 2.11 & 1.91 & 2.14 \\
\hline $\mathrm{Al}(\mathrm{VI})$ & 0.26 & 0.06 & 0.11 & 0.00 & 0.47 & 0.74 & 0.47 \\
\hline $\mathrm{Ti}$ & 0.44 & 0.42 & 0.39 & 0.38 & 0.38 & 0.38 & 0.47 \\
\hline $\mathrm{Fe}^{3+}$ & 0.48 & 0.44 & 0.43 & 0.43 & 0.53 & 0.55 & 0.55 \\
\hline $\mathrm{Mn}$ & 0.08 & 0.07 & 0.06 & 0.06 & 0.07 & 0.07 & 0.06 \\
\hline $\mathrm{Mg}$ & 1.38 & 1.27 & 1.34 & 1.34 & 0.64 & 0.62 & 0.63 \\
\hline $\mathrm{Fe}^{2+}$ & 3.35 & 3.54 & 3.67 & 3.54 & 3.53 & 3.65 & 3.42 \\
\hline $\mathrm{Na}$ & 0.01 & 0.01 & 0.04 & 0.03 & 0.03 & 0.03 & 0.05 \\
\hline $\mathrm{K}$ & 1.87 & 1.89 & 1.78 & 1.79 & 1.87 & 1.93 & 1.86 \\
\hline $\mathrm{Ca}$ & 0.00 & 0.00 & 0.00 & 0.00 & 0.01 & 0.00 & 0.01 \\
\hline $\mathrm{Fe}^{2+} / \mathrm{Fe}^{2++} \mathrm{Fe}^{3+}$ & 0.87 & 0.89 & 0.90 & 0.89 & 0.87 & 0.87 & 0.86 \\
\hline $\mathrm{T}^{\circ} \mathrm{C}$ & 750.56 & 737.33 & 729.59 & 727.20 & 700.41 & 700 & 728.69 \\
\hline $\log (\mathrm{fO} 2)$ & -14.92 & -15.09 & -15.36 & -15.51 & -16.09 & -16.28 & -15.53 \\
\hline
\end{tabular}

Homrat El-Girigab granites classified as alkali-feldspar granite (Fig. 5a) on ANOR-Q́ diagram (Streckeisen \& Le Maitre, 1979). Eyal et al. (2010) distinguished two sub-stages of alkaline suites in Sinai: a) an early sub-stage ( $\sim 610-600 \mathrm{Ma})$ formed syenogranites, which were preceded by monzodiorite; b) a later alkaline sub-stage ( $608-580 \mathrm{Ma})$ including syenogranites, alkali-feldspar granites and peralkaline riebekite granites. This later sub-stage was heralded by extensive volcanic activity (i.e. comparable with Dokhan volcanics in Homrat El-Girigab area). Furthermore, they suggested that, the alkaline granites were evolved mainly by fractional crystallization. The composition of the studied granites is compared Umm Shommer and Sharm alkali-feldspar granites (from Eyal et al., op. cit.). HGAFGs are so close in their composition to later sub-stage rocks (Table 2).

High Agpaitic Index value (AI = 1.1) of HGAFGs, enhances their alkaline natures (Liégeois et al., 1998). This alkaline affinity is further confirmed on $\mathrm{SiO}_{2}-\mathrm{Na}_{2} \mathrm{O}+\mathrm{K}_{2} \mathrm{O}-\mathrm{CaO}$ diagram (Frost \& Frost, 2008; Frost et al., 2001) and major elements discrimination diagram of Sylvester (1989), (Figs. 5b \& c, respectively). They are typical ferroan A-type granites as deduced from Figure 5d (Frost et al., 2001). This conclusion is strengthened by applying the classification diagrams of Whalen et al. (1987) and Eby, (1992), where they plot consistently in the fields of A-type granites (Figs. 5e and 4f, respectively). Their plotting in Field $\mathrm{A}_{2}$ (4f after Eby, 1992) implies their mantle-derived origin in an anorogenic tectonic setting.

$\mathrm{H}_{2} \mathrm{O}$ were determined by stoichiometry calculations. $\mathrm{Fe}^{3+} / \mathrm{Fe}^{2+}$ were calculated based on the method of Lin and Peng (1994); ( ${ }^{\circ} \mathrm{C}$ ) temperature of crystallization and Oxygen fugacity buffer Log (fO2) of biotites calculated according to the equation of Huebner \& Sato (1970). 
Elwan, W.

Table 2. Major elements (wt. \%), trace elements (ppm) analyses of HGAFGs.

\begin{tabular}{|c|c|c|c|c|c|c|c|c|c|}
\hline Rock & \multicolumn{6}{|c|}{ Alkali-feldspar granites } & \multirow[b]{2}{*}{ Average } & \multirow{2}{*}{$\begin{array}{c}\mathrm{US} \\
\mathrm{AFG}\end{array}$} & \multirow{2}{*}{$\begin{array}{c}\mathrm{SH} \\
\mathrm{AFG}\end{array}$} \\
\hline Oxides & 33 & 21 & 20 & 18 & 14 & 9 & & & \\
\hline $\mathrm{SiO}_{2}$ & 70.01 & 70.78 & 71.97 & 70.74 & 72.41 & 72.91 & 71.47 & 69.5 & 71.69 \\
\hline $\mathrm{TiO}_{2}$ & 0.23 & 0.20 & 0.11 & 0.17 & 0.13 & 0.14 & 0.16 & 0.55 & 0.30 \\
\hline $\mathrm{Al}_{2} \mathrm{O}_{3}$ & 13.73 & 14.25 & 13.79 & 13.68 & 13.85 & 13.79 & 13.85 & 14 & 13.41 \\
\hline $\mathrm{Fe}_{2} \mathrm{O}_{3} \mathrm{t}$ & 1.78 & 1.71 & 0.81 & 1.44 & 0.93 & 1.30 & 1.33 & 1 & 1.69 \\
\hline $\mathrm{MnO}$ & 0.04 & 0.03 & 0.01 & 0.03 & 0.02 & 0.03 & 0.03 & 0.06 & 0.08 \\
\hline $\mathrm{MgO}$ & 0.31 & 0.24 & 0.16 & 0.24 & 0.18 & 0.13 & 0.21 & 0.2 & 0.29 \\
\hline $\mathrm{CaO}$ & 0.96 & 0.60 & 0.75 & 0.68 & 0.66 & 0.80 & 0.74 & 0.6 & 0.83 \\
\hline $\mathrm{Na} 2 \mathrm{O}$ & 5.40 & 6.03 & 5.78 & 5.43 & 6.30 & 5.33 & 5.71 & 4.6 & 4.16 \\
\hline $\mathrm{K}_{2} \mathrm{O}$ & 5.85 & 5.38 & 5.21 & 5.49 & 4.54 & 5.34 & 5.30 & 5.2 & 5.53 \\
\hline $\mathrm{P}_{2} \mathrm{O}_{5}$ & 0.05 & 0.03 & 0.01 & 0.01 & 0.01 & 0.01 & 0.02 & - & 0.06 \\
\hline L.O.I & 1.10 & 0.30 & 0.80 & 1.70 & 0.60 & 0.60 & 0.85 & 0.3 & 0.61 \\
\hline Total & 99.46 & 99.55 & 99.40 & 99.62 & 99.65 & 100.37 & 99.68 & 99.85 & 99.97 \\
\hline $\mathrm{F}$ & 1310 & 1620 & 1720 & 1380 & 1680 & 1690 & 1566.67 & - & - \\
\hline $\mathrm{Ga}$ & 50 & 30 & 30 & 40 & 40 & 45 & 39.17 & 16 & 25 \\
\hline $\mathrm{Ba}$ & 240 & 120 & 102 & 94 & 35 & 105 & 116.00 & 332 & 317.5 \\
\hline $\mathrm{Rb}$ & 300 & 280 & 330 & 410 & 200 & 250 & 295.00 & 135 & 137.5 \\
\hline $\mathrm{Sr}$ & 90 & 60 & 50 & 67 & 30 & 25 & 53.67 & 57 & 43 \\
\hline $\mathrm{Nb}$ & 70 & 90 & 110 & 140 & 110 & 100 & 103.33 & 15 & 42.5 \\
\hline $\mathrm{Y}$ & 89 & 90 & 78 & 74 & 69 & 87 & 81.17 & 24 & 50 \\
\hline $\mathrm{Zr}$ & 290 & 310 & 250 & 270 & 200 & 230 & 258.33 & 180 & \\
\hline $\mathrm{Zn}$ & 80 & 60 & 30 & 30 & 40 & 40 & 46.67 & & \\
\hline Th & 10 & 30 & 50 & 20 & 20 & 15 & 24.17 & 12.7 & 15.25 \\
\hline $\mathrm{Q}$ & 20.15 & 19.17 & 22.19 & 21.32 & 22.33 & 23.52 & 21.45 & & \\
\hline Or & 34.58 & 31.79 & 30.77 & 32.47 & 26.82 & 31.58 & 31.34 & & \\
\hline $\mathrm{Ab}$ & 38.01 & 43.34 & 41.92 & 39.77 & 45.99 & 41.17 & 41.70 & & \\
\hline Ns & 1.79 & 1.79 & 1.63 & 1.43 & 1.70 & 0.92 & 1.54 & & \\
\hline Hy & 0.76 & 0.59 & 0.40 & 0.60 & 0.46 & 0.32 & 0.52 & & \\
\hline Il & 0.08 & 0.06 & 0.02 & 0.06 & 0.04 & 0.07 & 0.06 & & \\
\hline $\mathrm{Ru}$ & 0.19 & 0.17 & 0.10 & 0.14 & 0.11 & 0.10 & 0.14 & & \\
\hline Ap & 0.12 & 0.08 & 0.02 & 0.03 & 0.03 & 0.01 & 0.05 & & \\
\hline $\mathrm{Fr}$ & 1.24 & 0.78 & 1.03 & 0.93 & 0.90 & 1.10 & 1.00 & & \\
\hline $\mathrm{mg} \#$ & 25.42 & 21.50 & 28.18 & 24.76 & 28.20 & 16.34 & 24.07 & & \\
\hline $\mathrm{AI}$ & 1.11 & 1.10 & 1.10 & 1.09 & 1.10 & 1.06 & 1.09 & 0.94 & 0.92 \\
\hline $\mathrm{T}_{\mathrm{Zr}}^{\circ} \mathrm{C}$ & 741.4 & 757.8 & 737.9 & 747.7 & 717.1 & 737.4 & 739.88 & & \\
\hline P kbar & 3.81 & 3.54 & 4.11 & 3.46 & 2.77 & 2.60 & 3.38 & & \\
\hline Depth km & 10.27 & 9.57 & 11.08 & 9.33 & 7.48 & 7.01 & 9.12 & & \\
\hline $\mathrm{r} 1$ & -3.80 & -4.18 & -2.69 & -3.07 & -2.49 & -2.87 & -3.18 & & \\
\hline r2 & -6.69 & -6.57 & -5.16 & -5.64 & -5.01 & -4.78 & -5.64 & & \\
\hline
\end{tabular}

US AFG: Umm Shommer Alkali-feldspar granites; SH AFG: Sharm Alkali-feldspar granite (from Eyal et al., 2010); AI: Agpaitic Index $=$ molar $\mathrm{Al} / \mathrm{Na}+\mathrm{K}) ; \mathrm{T}_{\mathrm{Zr}}{ }^{\circ} \mathrm{C}$ : Zircon saturation thermometer calculated according to Watson \& Harrison 1983 and Boehnke et al. 2013; P kbar and Depth km: Crystallization pressures and depth of emplacement were calculated according to Yang (2017); r1, r2 discrimination values calculated by Agrawal (1995).

\section{Conditions of crystallization}

The crystallization temperatures of HGAFGs were calculated using zircon saturation $\left(\mathrm{T}_{\mathrm{Zr}}{ }^{\circ} \mathrm{C}\right)$ thermometer (Watson \& Harrison, 1983; Boehnke et al., 2013). They range from 717 to $758^{\circ} \mathrm{C}$. The pressures of crystallization of HGAFGs were estimated by using the following equation proposed by Yang (2017):

$$
\mathrm{P}=0.2426 \mathrm{x}(\mathrm{ab}+\mathrm{or})^{3}-46.397 \mathrm{x}(\mathrm{ab}+\mathrm{or})^{2}+2981.3 \times(\mathrm{ab}+\mathrm{or})-64224
$$

The pressures range from 2.60 to 4.11 (Table 2), while the depths of emplacement of HGAFGs were calculated depending on the estimated pressure by using Yang (op. cit.) calculations of the depth, which suppose that $1 \mathrm{~kb}$, equivalent to $2.7 \mathrm{~km}$ depth assuming that, the density of continental crust is 2.85 $\mathrm{g} / \mathrm{cm} 3$ and the pressure is entirely lithostatic. They range from 7 to $11 \mathrm{~km}$ (Table 2). 
Petrogenesis of Homrat El-Girigab alkali-feldspar granites

Fig. 4: (a-e) a) $10 * \mathrm{TiO}_{2}-\mathrm{FeO}$ $+\mathrm{MnO}-\mathrm{MgO}$ diagram (Nachit et al., 2005), distinguishing between magmatic, re-equilibrated and neoformed biotite; $b$ ) Alt versus $\mathrm{Fe}^{2+} /\left(\mathrm{Fe}^{2+}+\mathrm{Mg}\right.$ ) diagram (Rieder et al., 1999) for classification of the studied trioctahedral micas; $\mathrm{c}$ ) Alt-Mg biotite diagram (Nachit et al., 1985); d) $\mathrm{Fe}^{2+}-\mathrm{Fe}^{3+}-\mathrm{Mg}$ diagram (Wones \& Eugster, 1965), Oxygen fugacity buffers: quartz - fayalite- magnetite (QFM), nickel - nickel oxide (NNO), hematite-magnetite (HM).; e) Log fO2 - ${ }^{\circ} \mathrm{C}$ ternary diagram for the biotite stability as a function of $\mathrm{Fe} /(\mathrm{Fe}+\mathrm{Mg})$ at pressure of 2070 bars (Wones \& Eugester, 1965), Arrows represent oxidizing and reducing trends.
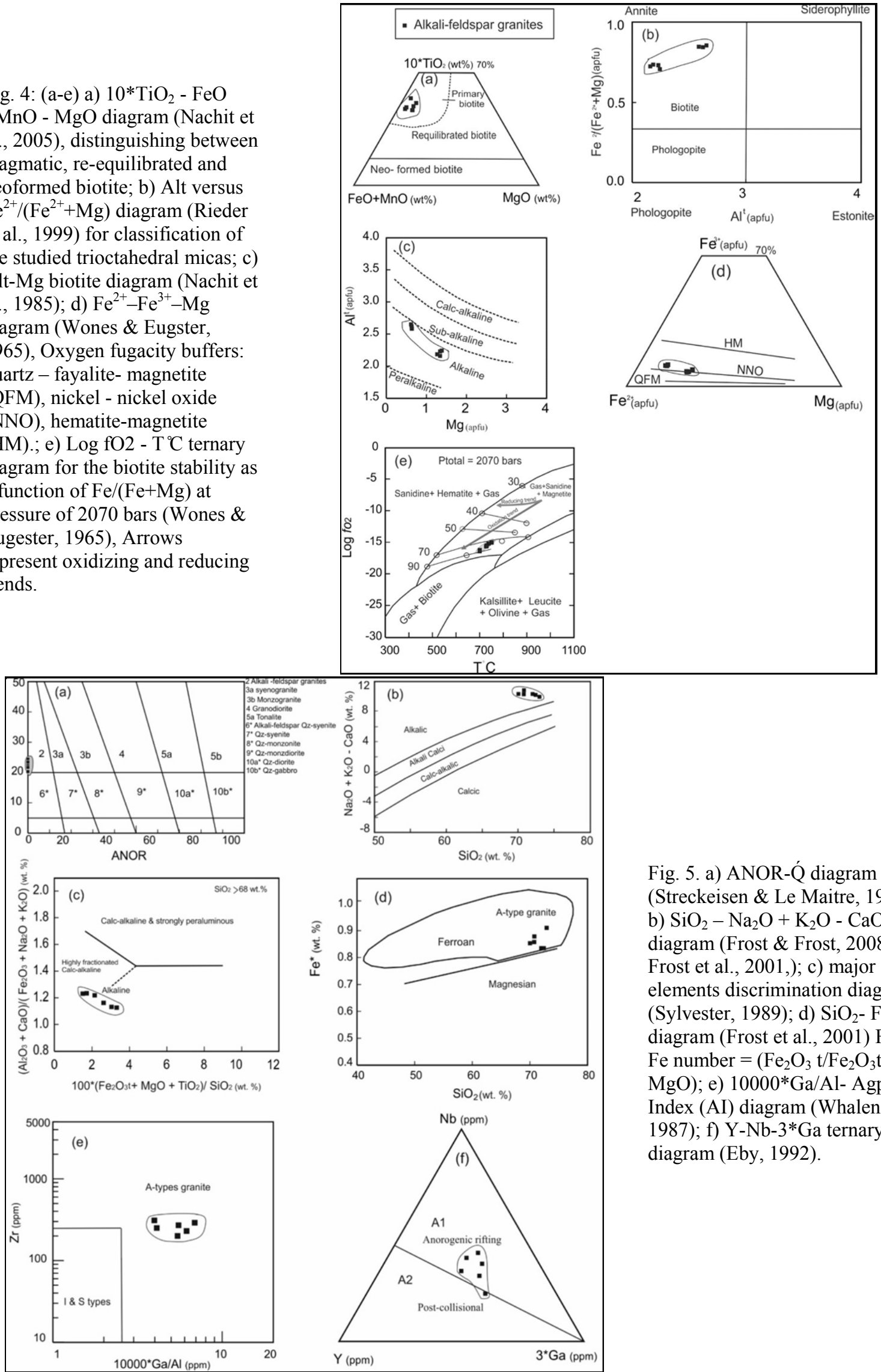

Fig. 5. a) ANOR-Q́ diagram (Streckeisen \& Le Maitre, 1979); b) $\mathrm{SiO}_{2}-\mathrm{Na}_{2} \mathrm{O}+\mathrm{K}_{2} \mathrm{O}-\mathrm{CaO}$ diagram (Frost \& Frost, 2008; Frost et al., 2001,); c) major elements discrimination diagram (Sylvester, 1989); d) $\mathrm{SiO}_{2}-\mathrm{Fe}^{*}$ diagram (Frost et al., 2001) Fe*: $\mathrm{Fe}$ number $=\left(\mathrm{Fe}_{2} \mathrm{O}_{3} \mathrm{t} / \mathrm{Fe}_{2} \mathrm{O}_{3} \mathrm{t}+\right.$ $\mathrm{MgO}$ ); e) $10000 * \mathrm{Ga} / \mathrm{Al}$ - Agpaitic Index (AI) diagram (Whalen et al., 1987); f) Y-Nb-3*Ga ternary diagram (Eby, 1992). 
Elwan, W.

\section{DISCUSSION}

\section{Tectonic setting}

On r1-r2 multivariate discriminant diagram (Agrawal, 1995), HGAFGs fall in anorogenic granite field (Fig. 6a). In $\mathrm{SiO}_{2}-\log \left[\mathrm{CaO} /\left(\mathrm{Na}_{2} \mathrm{O}+\mathrm{K}_{2} \mathrm{O}\right)\right]$ diagram (Brown, 1982), HGAFGs samples are plotted on extensional tectonic setting (Fig. 6b). According to $\mathrm{K}_{2} \mathrm{O}-\mathrm{Na}_{2} \mathrm{O}-3^{*} \mathrm{CaO}$ ternary diagram (Liégeois et al., 1998). HGAFGs fall in Late-Shear Alkaline granite series (Fig. 6d). Alkaline magmatism is linked to major lithospheric structures, whether it is post-collisional (Liégeois \& Black, 1987; Duchesne et al., 1997) or anorogenic (Black et al., 1985; Moreau et al., 1994). Alkaline magmatism is not always present in post-collisional settings, but when it occurs it is very similar to true anorogenic alkaline manifestations (Black et al., op. cit.; Sylvester, 1989). Nb/Y- Rb/Y diagram (Pearce et al., 1990), the HGAFGs samples plot in between lower crust composition and they follow Within-Plate enrichment trend (Fig. 6c). According to $\mathrm{Sr}-\mathrm{Rb}$ diagram (Condie, 1973), HGAFGs magmatic source was generated at depth more than $30 \mathrm{~km}$ (Fig. 6d) and emplaced later at shallower depth. The ANS crustal thickness is around $40 \mathrm{~km}$ (Al-Damegh et al., 2005).

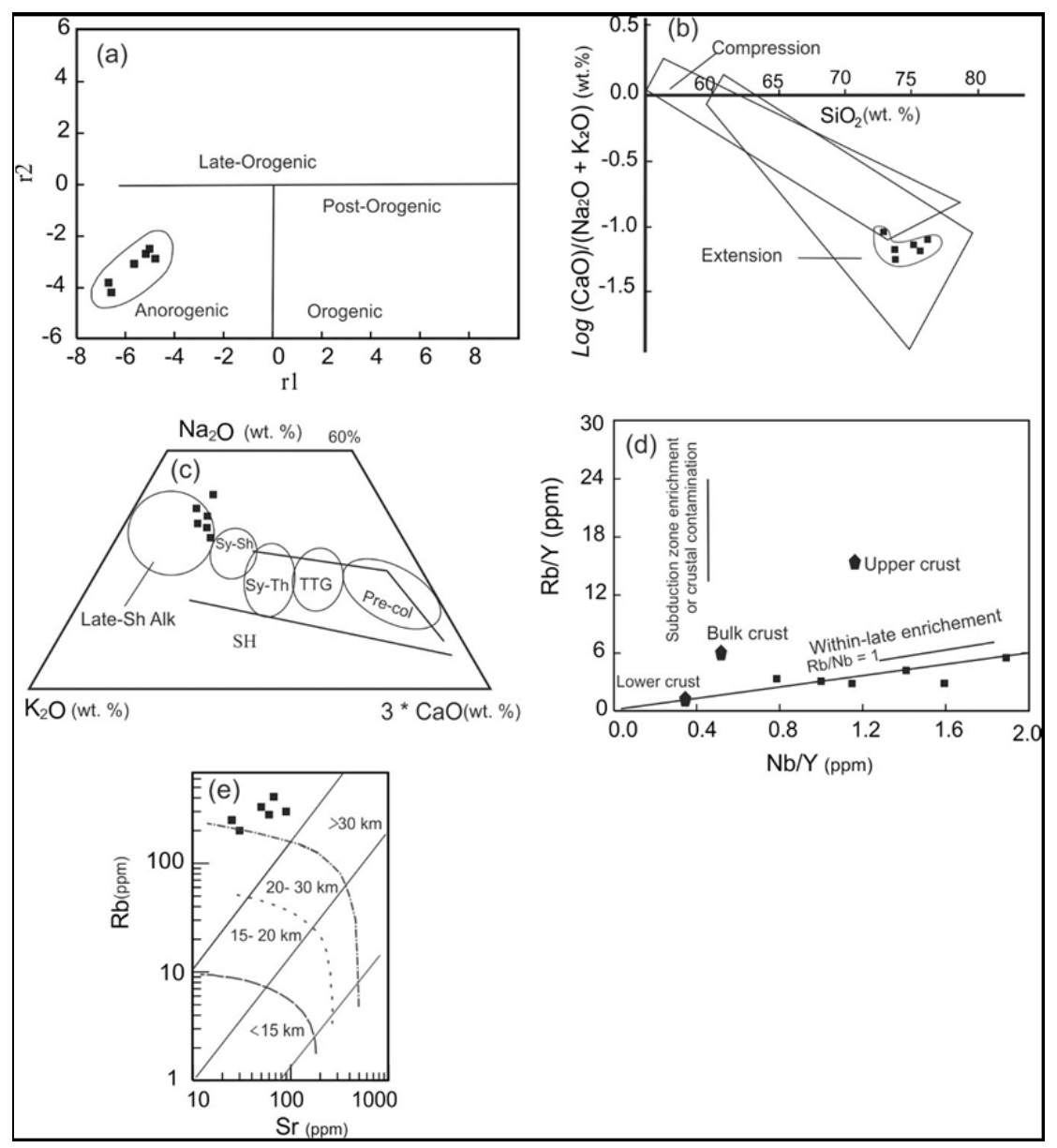

Fig. 6. a) r1-r2 multivariate discriminant diagram (Agrawal, 1995); b) $\mathrm{SiO}_{2}$-log $\left[\mathrm{CaO} /\left(\mathrm{Na}_{2} \mathrm{O}+\mathrm{K}_{2} \mathrm{O}\right)\right]$ diagram (Brown, 1982); c) $\mathrm{K}_{2} \mathrm{O}-\mathrm{Na}_{2} \mathrm{O}-$ $3 * \mathrm{CaO}$ ternary diagram (Liégeois et al., 1998); d) $\mathrm{Nb} / \mathrm{Y}-\mathrm{Rb} / \mathrm{Y}$ diagram, the compositions of lower-, bulk-, and upper crusts are after Taylor \& McLennan (1985); e) $\mathrm{Sr}-\mathrm{Rb}$ binary diagram fields after Condie (1973).

\section{Petrogenesis}

Ab- Q- Or- $\mathrm{H}_{2} \mathrm{O}-\mathrm{F}$ plots of normative compositions show that the HGAFGs fall just close to the minima melt at $5 \mathrm{kbar}$ with water pressure $\mathrm{a}_{\mathrm{H} 2 \mathrm{O}} 0.5$ and at $2 \%$, F (Fig. 7a), suggesting that the HGAFGs does not represent $100 \%$ liquid composition, or that the melt was water-undersaturated (Johannes \& Holtz, 1990). This trend is consistent with the moving positions of the minima for the water-saturated Q-Ab-Or system with increasing fluorine and water content. Many studies refer to the role halogens $(\mathrm{F}$ and $\mathrm{Cl})$ as complexing agents for REE, Y and HFSE (Charoy \& Raimbault, 1994; Audétat et al., 2000; Agangi et al., 2010). The origin of the F-rich fluids either are primary magmatic origin (Dostal \& Chatterjee, 1995; 


\section{Petrogenesis of Homrat El-Girigab alkali-feldspar granites}

Agangi op. cit.) or as secondary metasomatic origin (Nurmi \& Haapala, 1986). HGAFGs are fluorine-rich (1.5 F wt. \%, on average; Table 2). The appearance of fluorite in CIPW normative values (Table 2) and presence fluorite, support that, the fluorine has a role of in the genesis of these granites. In addition, MFW plot of Ohta and Arai (2007) used to differentiate between fresh magmatic and altered samples. All HGAFGs samples follow the magmatic trend (Fig. 7b). In addition, there is no any unusual F-rich rocks surrounds HGAFGs to be a source for leaching fluorine through hydrothermal processes. Furthermore, the lack of any metasomatic alteration (i.e. albitization) support the magmatic origin of F-rich fluids. Agangi et al. (2010) supposed the following scenario of F-rich fluids formation, which start with the crystallization of quartz and feldspar from the magmatic source, yielding a late-stage magmatic fluid enriched in $\mathrm{F}$ and to lesser extent in water content with fractionation of anhydrous quartzo-feldspathic components. Fluorine dissolved in the magma during late stages of magmatic evolution, causing REE and HFSE complexing and mobilizing.

Fig. 7. a) Ab-Q-Or- $\mathrm{H}_{2} \mathrm{O}-\mathrm{F}$, dotted lines show the location of minima melt composition at saturated water pressure ranging from 0.5 to 10 kbar (Winkler et al., 1975). Solid line shows the minima melt at 1 kbar with excess $\mathrm{H}_{2} \mathrm{O}$ at $1 \%, 2 \%$, 4\% F (Manning, 1981); b) FMW diagram (Ohta and Arai, 2007) for chemical weathering of igneous rock $\mathrm{M}$ : mafic, F: felsic $\mathrm{W}$ : weathering; c) $\mathrm{SiO}_{2}-\mathrm{Al}_{2} \mathrm{O}_{3}$ diagram represents comparison between the compositions of the investigated granites with the experimental work of the melting of a basaltic/amphibolitic source (Bread and Lofgren, 1991); d) $\mathrm{SiO}_{2}-\mathrm{Rb} / \mathrm{Sr}$ binary diagram (Blevin 2004), PM: partial melting, FC: fractional crystallization trends from (Pearce et al., 1990); e) $\mathrm{Zr}-\mathrm{Th} / \mathrm{Nb}$ diagram, trends of FC: fractional crystallization, AFC: assimilationfractional crystallization, and BA: bulk assimilation are from Nicolae and Saccani (2003); f) Rb/Ba$\mathrm{Rb} / \mathrm{Sr}$ diagram, fractionation trends of Pl: plagioclase, Kf: k-feldspar.

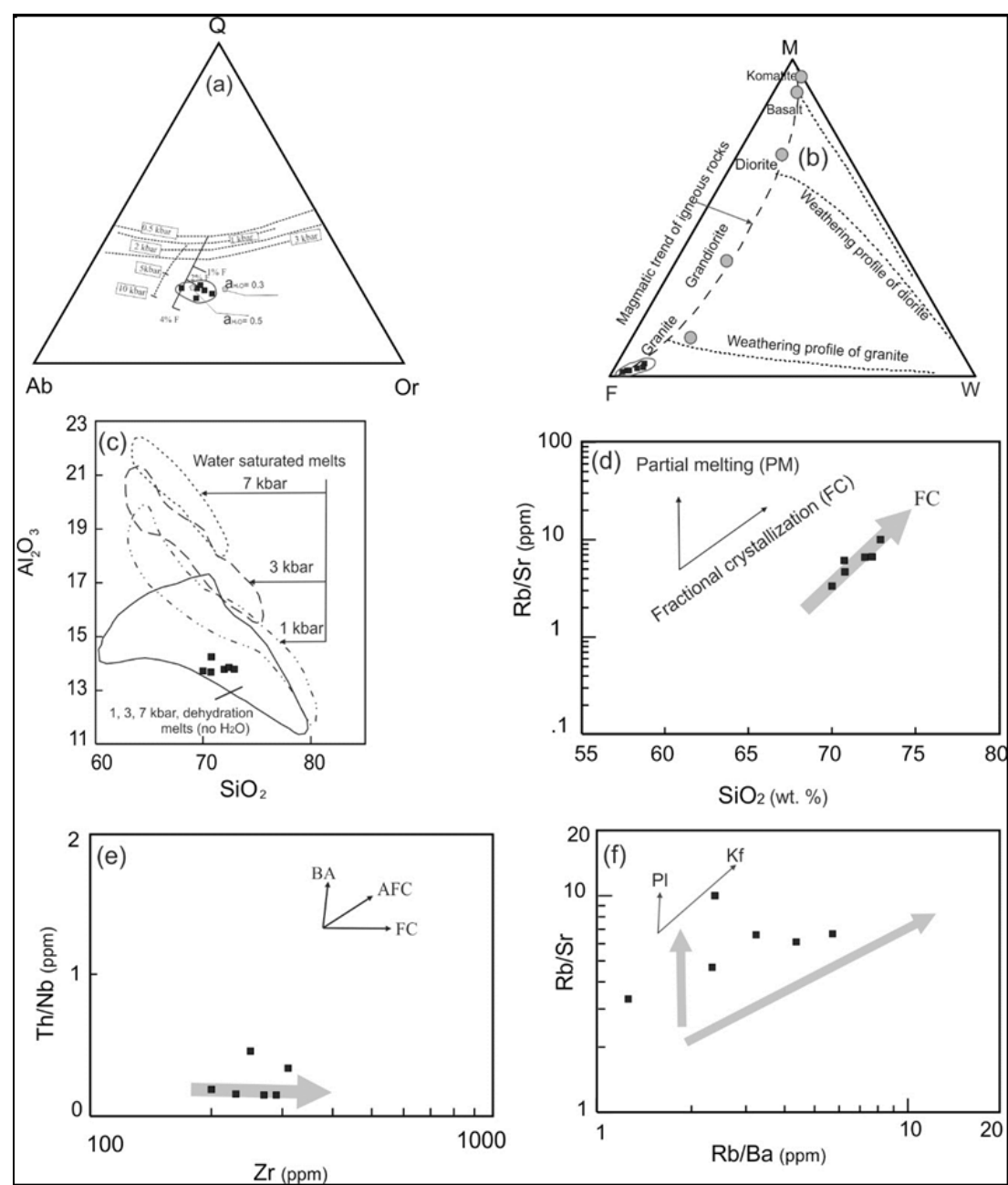

Finally, these F-enriched fluids migrate toward the roof of the pluton, giving rise to formation of accessory minerals, in interstices spaces between early formed minerals (i.e. feldspar and quartz). According to Moreno et al. (2014) the F-rich melt could be formed through carbonatite and amphibolerich mantle wedge as it broke down generates F-rich melt.

$\mathrm{SiO}_{2}-\mathrm{Al}_{2} \mathrm{O}_{3}$ binary diagram (Bread \& Lofgren, 1991) shows the compositional similarities between the investigated HGAFGs analyses and experimental results of 20-25\% dehydration melting of amphibolitic/basaltic sources (i.e. no $\mathrm{H}_{2} \mathrm{O}$ added). HGAFGs samples fall in the field of amphibolitic source at 1, 3, 7 kbar (Fig. 6c). Both $\mathrm{SiO}_{2}-\mathrm{Rb} / \mathrm{Sr}$ (Fig. 7d after Blevin, 2004) and $\mathrm{Zr}-\mathrm{Th} / \mathrm{Nb}$ (Fig. 6e after Nicolae and Saccani, 2003) diagrams reveal that, fractional crystallization was probably the main process 


\section{Elwan, W.}

to be accounted for the evolution of HGAFGs. Fractionation of plagioclase and K-feldspar could be responsible for the depletion of $\mathrm{Ba}$ (from 240 to $35 \mathrm{ppm}$ ) and $\mathrm{Sr}$ (90 to $25 \mathrm{ppm}$ ) and the enrichment of $\mathrm{Rb}$ (from 200 to 410 ppm, cf. Table 2 and Fig. 7f).

\section{Geodynamic implications}

The widely distributed calc-alkaline and alkaline coeval rocks in the ANS explained by extensional collapse that follows continental collision (650-600 Ma) between the East and West Gondwana (Abdelsalam et al. 2002, Fig. 8a). From one side, the continental collision led to extensive crustal thickening (Stern 1994, 2002; Abdelsalam\& Stern 1996; Stoeser \& Frost 2006; Stern 2008; Avigad \& Gvirtzman 2009, Fig. 8b). On the other side, the extensional collapse (600-550Ma) led to thinning of lithosphere (Fig. 7c). Extensional collapse was controlled by lithospheric delamination and slab breakoff (Davies \& von Blackenburg, 1995; Farahat et al. 2007; Avigad \& Gvirtzman op. cit.; Eyal et al. 2010).

During late collisional stage (630-610 Ma), due to the begging of the slab breakoff, a slab window opened, which enhancing the heat flux provided by the upwelling asthenosphere, causing melting process (Bonin, 2004; Fig. 8b). This melts produced late-collisional calc-alkaline magmatism in the northern ANS (Fig. 8b).

The next late collisional to early post-collisional stage (610-590 Ma) commenced $\sim 20$ m.y. later on, the rapid uplift of the crust due to the slab detachment caused decompression melting in the lithosphere. This mafic mantle-derived melt underplate the juvenile crust, causing widespread magmatism and producing coeval calc-alkaline/alkaline magmas (Fig. 8c).

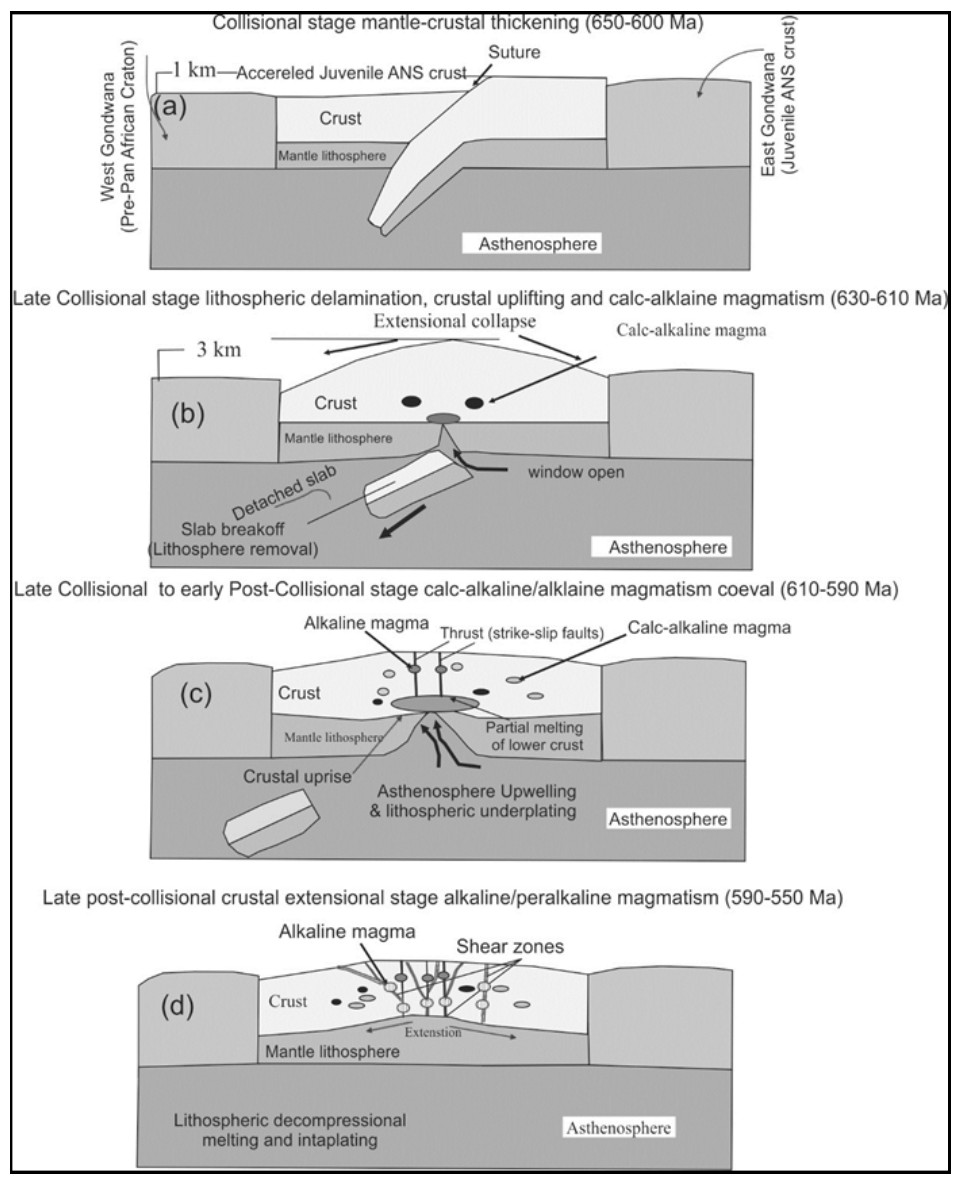

Fig. 8: Sketch showing the tectonomagmatic evolution of late post-collisional alkali-feldspar granites of Homrat ElGirigab (modified after Elwan et al., 2019), a) Collision between East and West of Gondwana (650-600 Ma), which characterized by mantle/crust thickening; b) Beginning extensional collapse at $\sim 600$ $\mathrm{Ma}$ and slab breakoff as a consequence of crustal thickening. Due to slab breakoff a slab window opened, which enhance heat flux provided by the upwelling asthenosphere, causing melting. This melts produced late-collisional calc-alkaline magmatism; c) Slab detaches and sink away and the detached slab or lithospheric removal allows asthenosphere to rise or asthenosphere upwelling causing melting and formation of calc-alkaline /alkaline magmatism; d) Rapid lithospheric uplift and intraplating caused melting to produce alkaline/peralkaline magmatism in ANS, which facilitated by strike-slip faults and shear-zones.

During the late post-collisional crustal extensional stage (590-550 Ma), the effect of lithospheric delamination, and thus asthenospheric uprise, likely diminishes. Due to the rapid uplift mantle-derived 
melts intraplate the middle-lower crustal levels forming alkaline/peralkaline magmatism of HGAFGs, which facilitated by the abundance of strike-slip faults and shear zones (Fig. 8d)

As the HGAFGs supposed to represent $A_{1}$ anorogenic granites, they most probably originated in crustal extension regime (Grebennikov, 2014). They formed in a within-plate settings; either in the intracontinental system or near the divergent boundaries, where formation of igneous rocks is related to faulting, shear zones and mantle melts penetration (Dobretsov, 2003). HGAFGs represent late shear alkaline granites (Figs. 5c, and 7d), where mantle-derived mafic melts intraplate the lower crustal levels, facilitated by the abundance of strike-slip faults and shear zones. HGAFGs were generated from lower crustal amphibolitic source through fractional crystallization (Figs. $5 \mathrm{~d} \& \mathrm{e}, 6 \mathrm{c}, \mathrm{d} \&$ f). The abundant amphibole and carbonatite in the mantle wedge (Moreno et al., 2014) broke down to generate F-rich melt. Partial melting of the hot juvenile lower crust injected with such melt then produced granite with A-type characteristics. The mantle components in the mafic melt were metasomatized by subduction released fluids (i.e. F-rich melts) are easier to be partially melted, which consequently eliminated subduction signatures and formed HGAFGs magma.

\section{CONCLUSION}

1- Homrat El-Girigab area located at northern Eastern Desert and it is covered by Dokhan volcanics, which intruded by alkali-feldspar granites.

2- The biotite in Homrat El-Girigab alkali-feldspar granites were crystallized from alkaline source under NNO Oxygen buffer and oxygen fugacity (log fO2) range from -14.92 to -16.28 i.e. oxidized conditions.

3- Homrat El-Girigab alkali-feldspar granites are alkaline, ferroan anorogenic A-type granites. They are belong to A1-subtype anorogenic granites.

4- Alkali-feldspar granites were crystallized under temperatures range from 700 to $758^{\circ} \mathrm{C}$, pressures 3 to 4 kbar and emplaced at depths range from 7 to $11 \mathrm{~km}$.

The alkali-feldspar granites were emplaced during the late post-collisional crustal extensional stage, where mantle-derived mafic melts intraplate the lower crustal levels, which facilitated by the abundance of strike-slip faults and shear zones. Homrat El-Girigab granites were derived from lower crustal amphibolitic source and evolved by fractional crystallization.

\section{ACKNOWLEDGMENT}

The author is very grateful to Prof. M. Putiš, Department of Mineralogy and Petrology, Comenius University, Bratislava, Slovakia for offering the microprobe analyses.

\section{REFERENCES}

Abd El- Ghafour, N. G. A, Khalil, M. H., Gharib, M. E., Abd Latif, M. L. (2001): Mineralogical and radioactive properties of some Egyptian granitoid rocks and their suitability for ornamental stones. HNRC J., 8: 64-86.

Abdelsalam, M.G. and Stern, R. J. (1996): Sutures and shear zones in the Arabian Nubian Shield. J. Afr. Earth Sci., 23, 289-310.

Abdelsalam, M.G., Liegeois, J.-P. and Stern, R. J. (2002): The Saharan Metacraton. J. Afr. Earth Sci., 34: 119-136.

Agangi, A., Kamenetsky, V.S. and McPhie, J. (2010): The role of fluorine in the concentration and transport of lithophile trace elements in felsic magmas: insights from the Gawler Range Volcanics, South Australia. Chem. Geol., 273: 314-325.

Agrawal, S. (1995): Discrimination between late-orogenic, post-orogenic, and anorogenic granites by major element compositions. Jour. Geol., 103: 529-537.

Al-Damegh, K., Sandvol, E., Barazangi, M. (2005): Crustal structure of the Arabian plate: new constraints from the analysis of teleseismic receiver functions, Earth Planet. Sci. Lett., 231: 177. 
Elwan, W.

Ali, K.A., Jeon, H., Li, A., Andresen, S.-Q., Harbi, H.M. and Hegner, E. (2014): U-Pb zircon geochronology and $\mathrm{Nd}-\mathrm{Hf}-\mathrm{O}$ isotopic systematics of the Neoproterozoic Hadb adh Dayheen ring complex, Central Arabian Shield, Saudi Arabia. Lithos, (206- 207): 348-360.

Ali, K.A., Stern, R.J., Manton, W.I., Kimura, J.I. and Khamees, H.A. (2009): Geochemistry, Nd isotopes and U-Pb SHRIMP dating of Neoproterozoic volcanic rocks from the Central Eastern Desert of Egypt: new insights into the 750 Ma crust-forming event. Precamb. Res., 171: 1-22.

Audétat, A., Günther, D. and Heinrich, C.A. (2000): Magmatic-hydrothermal evolution in a fractionating granite: a microchemical study of the Sn-W-F-mineralized Mole Granite (Australia). Geochim. Cosmochim. Acta 19: 3373-3393.

Avigad, A., Sandler, A., Kolodner, K., Stern, T.J., McWilliams, M., Miller, N. and Beyth, M. (2005): Mass-production of Cambro-Ordovician quartz-rich sandstone as a consequence of chemical weathering of Pan-African terranes: environmental implications. Earth Planet. Sci. Lett. 240: 818-826.

Avigad, D. and Gvirtzman, Z. (2009): Late Neoproterozoic rise and fall of the northern Arabian-Nubian Shield: the role of lithospheric mantle delamination and subsequent thermal subsidence. Tectonophy., 477: 217-228.

Azer, M. K. (2013): Late Ediacaran (605-580 Ma) post-collisional alkaline magmatism in the ArabianNubian Shield: A case study of Serbal ring-shaped intrusion, southern Sinai, Egypt. J. Asian Earth Sci., 77: 203-223.

Be'eri-Shlevin, Y., Katzir, Y. and Valley, J. W. (2009): Crustal evolution and recycling in a juvenile continent: oxygen isotope ratio of zircon in the northern Arabian Nubian Shield. Lithos 107: 169-184.

Be'eri-Shlevin, Y., Katzir, Y., Blichert-Toft, J., Kleinhanns, I.C. and Whitehouse, M. (2010): Nd-Sr-Hf-O isotope provinciality in the northernmost Arabian-Nubian Shield: implications for crustal evolution. Contrib. Miner. Petrol., 160:181-201.

Be'eri-Shlevin, Y., Samuel, M.D., Azer, M.K., Ramo, O.T., Whitehouse, M.J. and Moussa, H.E. (2011): The Ediacaran Ferani and Rutig volcano-sedimentary successions of the northernmost Arabian-Nubian Shield (ANS): New insights from zircon $\mathrm{U}-\mathrm{Pb}$ geochronology, geochemistry and $\mathrm{O}-\mathrm{Nd}$ isotope ratios. Precamb. Res., 188: 21-44.

Beard, J. S. and Lofgren G. E. (1991): Dehydration melting and water - saturated melting of basaltic and andesitic greenstone and amphibolites at 1, 3, and $6.9 \mathrm{~kb}$. J. Petrol., 32:365 - 401.

Bielski, M., Jager E. and Steinitz, G. (1979): The geochronology of Iqna granite (Wadi Kid Pluton), southern Sinai. Contrib. Mineral. Petrol., 70:159-165.

Black, R., Lameyre, J. and Bonin, B. (1985): The structural setting of alkaline complexes. J. Afr. Earth Sci., 3: 5-16.

Blevin, P.L. (2004): Redox and compositional parameters for interpreting the granitoid metallogeny of eastern Australia: Implications for gold-rich ore systems. Resour. Geol., 54 (3): 241-252.

Boehnke, P., Watson, E.B., Trail, D., Harrison, T.M., and Schmitt, A.K. (2013): Zircon saturation rerevisited: Chem. Geology., 351: 324-334.

Bonin, B. (2004): Do coeval mafic and felsic magmas in post-collisional to within-plate regimes necessarily imply two contrasting, mantle and crustal, sources? A review. Lithos 78: 1-24.

Brown, G.C. (1982): Calc-alkaline Intrusive Rocks: Their Diversity, Evolution and Relation to Volcanic Arcs. In: Thorpe, R. S., (ed.), Andesites-Orogenic Andesites and Related Rocks. John Wiley and Sons, New York. 437-461.

Charoy, B. and Raimbault, L. (1994): Zr-, Th-, and REE-rich biotite differentiates in the A-type granite pluton of Suzhou (Eastern China): the key role of fluorine. J. Petrol., 35: 919-962.

Condie, K. C. (1973): Archean Magmatism and Crustal Thickening. Geol. Soc. Amer Bull., 84: 2981-2991.

Condie, K. C., O'Neill, C., Richard C. A. (2009): Evidence and implications for a widespread magmatic shutdown for 250 My on Earth. Earth Planet. Sci. Lett., 282: 294-298.

Davies, J. H. and von Blanckenburg, F. (1995): Slab breakoff: A model of lithosphere detachment and its test in the magmatism and deformation of collisional orogens. Earth Planet. Sci. Lett., 129(1-4): 85-102.

Dobretsov, N. L. (2003): Mantle plumes and their role in the formation of anorogenic granitoids. Geologiya i Geofizika. Russ. Geol Geophy., 44 (12): 1243-1261, (1199-1218). 
Petrogenesis of Homrat El-Girigab alkali-feldspar granites

Dostal, J. and Chatterjee, A. K. (1995): Origin of topaz-bearing and related peraluminous granites of the late Devonian Davis Lake pluton, Nova Scotia, Canada: crystal versus fluid fractionation. Chem. Geol., 123: 67-88.

Drysdall, A. R., Jackson, N. J., Ramsay, C. R., Douch, C. J. and Hackett, A. D. (1984): Rare element mineralization related to Precambrian alkali granites in the northwest Arabian Shield. Econ. Geol., 79, 1366-1377.

Duchesne, J. C., Schärer, U., Liégeois, J.P., Vander Auwera, J. and Longhi, J. (1997): Tectonic Setting and Phase Diagram Constraints on the Origin of Proterozoic Anorthosites: The Craton Tongue Melting Model. Abstract, Copena, Trondheim, Norway.

Eby, G.N. (1992): Chemical subdivisions of A-type granitoids: Petrogenesis and tectonic implications. Geol., 20: 614-644.

El-Bialy, M.Z. (2010): On the Pan-African transition of the Arabian-Nubian Shield from compression to extension: the post-collision Dokhan volcanic suite of Kid-Malhak region, Sinai, Egypt. Gond. Res., 17: 26-43.

El-Bialy, M.Z. and Hassan, I.S. (2012): The late Ediacaran (580-590Ma) onset of anorogenic alkaline magmatism in the Arabian-Nubian Shield: Katherina A-type rhyolites of Gabal Ma'ain, Sinai,Egypt. Precamb. Res., (216-219): 1-22.

Elwan, W., Azzaz, S.A, Balasi, M.R and Amer, O. (2019): Petrogenesis of Maktali fractionated calcalkaline younger granitoids, Central Eastern Desert, Egypt. Arab. J. Geosci. (Accepted).

Eyal, M., Litvinovsky, B., Jahn, B.M., Zanvilevich, A. and Katzir, Y. (2010): Origin and evolution of post-collisional magmatism: Coeval Neoproterozoic calc-alkaline and alkaline suites of the Sinai Peninsula. Chem. Geol., 269: 153-179.

Farahat, E. S. and Azer, M. K. (2011): Post-collisional magmatism in the northern Arabian-Nubian Shield: The geotectonic evolution of the alkaline suite at Gebel Tarbush area, south Sinai, Egypt. Chemie der Erde, 7 (3): 247-266.

Farahat, E. S., Mohamed, H. A., Ahmed, A. F. and El Mahallawi, M. M. (2007): Origin of I- and A-type granitoids from the Eastern Desert of Egypt: implications for crustal growth in the northern ArabianNubian Shield. J. Afri. Earth Sci., 49: 43-58.

Frost, B. R. and, Frost C. D. (2008): A Geochemical Classification for Feldspathic Igneous Rocks. J. Petrol., 49 (11), 1955-1969.

Frost. B. R., Arculus, R.J., Barnes, C. G., Collins, W.J., Ellis, D. J. and Frost, C. D. (2001): A geochemical classification of granitic rocks. J. Petrol., 42: 2033-2048.

Grebennikov, A. V. (2014): A-type granites and related rocks: Petrogenesis and classification. Russ. Geol. Geophy., 55 (11): 1353-1366.

Huebner, J. S. and Sato, M. (1970): The oxygen fugacity-temperature relationships of manganese oxide and nickel oxide buffers. Amer. Mineral., 55: 934-952.

Johannes, W. and Holtz, F. (1990): Formation and composition of H2Oundersaturated granitic melts. In: Ashworth, J. R. and Brown, M. (eds.), High temperature and crustal anatexis. Unwin Hyman, London, 87-104.

Johnson, P. R., Andresen, A., Collins, A. S., Fowler, A. R., Fritz, H., Ghebrab, W., Kusky, T. and Stern, R. J. (2011): Late Cryogenian-Ediacaran history of the Arabian-Nubian Shield: a review of depositional, plutonic, structural, and tectonic event in the closing stages of the northern East African Orogen. J. Afr. Earth Sci., 61: 167-232.

Küster, D. (2009): Granitoid-hosted Ta mineralization in the Arabian-Nubian Shield: ore deposit types, tectono-metallogenetic setting and petrogenetic framework. Ore Geol. Rev., 35: 68-86.

Liégeois, J. P. and Black, R. (1987): Alkaline magmatism subsequent to collision in the Pan-African belt of the Adrar des Iforas. In: Fitton, J.G. and Upton, B.G.J. (eds.), Alkaline Igneous Rocks. The Geol. Soc., Blackwell, Oxford, 30: 381-401.

Liégeois, J. P., Navez, J., Hertogen, J. and Black, R. (1998): Contrasting origin of post-collisional high-K calc-alkaline and shoshonitic versus alkaline and peralkaline granitoids. The use of sliding normalization. Lithos, 45: 1-28.

Lin, W. W. and Peng, L. J. (1994): The Estimation of $\mathrm{Fe}^{3+}$ and $\mathrm{Fe}^{2+}$ Contents in Amphibole and Biotite from EMPA Data. J. Changchun Univ. Earth Sci., 24 (2), 155-162 (in Chinese with English Abstract). 
Elwan, W.

Manning, D. A. C. (1981): The effect of fluorine on liquidus phase relationships in the system Qz-Ab-Or with excess water at $1 \mathrm{~kb}$. Contrib. Miner. Petrol. 76: 206- 215.

Moghazi, A. M. (1999): Magma source and evolution of late Neoproterozoic granitoids in the Gabal El Urf area, Eastern Desert, Egypt: geochemical and $\mathrm{Sr}-\mathrm{Nd}$ isotopic constraints. Geol. Mag. 136: 285300.

Moghazi, A. M., Ali, K. A., Wilde, S. A., Zhou, Q., Andersen, T., Andresen, A., Abu El Enen, M. M. and Stern, R. J. (2012): Geochemistry, geochronology, and Sr-Nd isotopes of the Late Neoproterozoic Wadi Kid volcano-sedimentary rocks, Southern Sinai, Egypt: implications for tectonic setting and crustal evolution. Lithos, 154: 47-165.

Moghazi, A. M., Harbi, H. and Ali, K. A. (2011): Geochemistry of the Late Neoproterozoic Hadb adh Dayheen ring complex, Central Arabian Shield: Implications for the origin of rare-metal-bearing postorogenic A-type granites. J. Asian Earth Sci., 42(6): 1324-1340.

Moreau, C. Demaiffe, D., Bellion, Y. and Boullier A.-M. (1994): A tectonic model for the location of Palaeozoic ring complexes in A3 (Niger, West Africa). Tectonophy., 234: 129-146.

Moreno, J. A., Molina, J. F., Montero, P., Abu Anbar, M., Scarrow, J. H., Cambeses, A. and Bea, F. (2014): Unraveling sources of A-type magmas in juvenile continental crust: Constraints from compositionally diverse Ediacaran post-collisional granitoids in the Katerina Ring Complex, southern Sinai, Egypt. Lithos (192-195): 56-85.

Nachit, H., Ibhi, A., Abia, E. and Ben Ohoud, M. (2005): Discrimination between primary magmatic biotites, reequilibrated biotites and neoformed biotites. Comptes Randus Geosci., 350: 13-21.

Nachit, H., Razafimahefa, N., Stussi, J. M. and Carron, J. P. (1985): Composition chimique des biotites et typologie magmatiquc des granitoldes. Comptes Rendus Hebdomadaires de I'Academie des Sciences 301(11) : 813-818.

Nicolae, I. and Saccani, E. (2003): Petrology and geochemistry of the Late Jurassic calc-alkaline series associated to Middle Jurassic ophiolites in the South Apuseni Mountains (Romania). Schweiz. Mineral. Petrogr. Mitt., 83: 81-96.

Nurmi, P. A. and Haapala, I. (1986): The Proterozoic granitoids of Finland: granite types, metallogeny and relation to crustal evolution. Bull. Geol. Soc. Finland 58: 431-453.

Ohta, T., and Arai, H. (2007): Statistical empirical index of chemical weathering in igneous rocks: A new tool for evaluating the degree of weathering. Chem. Geol., 240: 280-297.

Pearce, J. A., Bender, J. F. and DeLong, S. E. (1990): Genesis of Collision Volcanism in Eastern Anatolia, Turkey. J. Volc. and Geother. Res., 44 (1-2): 189-229.

Rieder, M., Cavazzini, G. Yakonov, Y. S. D. Frank V. A., Gottardi G., Guggenheim, S., Koval, P.V., Müller, G., Nieva, A.M., Radoslovich, E.W., Robert, J-L., Sassi, F., Takeda, H., Weiss, Z. and Wones, D. R. (1999): Nomenclature of micas. Mineral. Mag., 63: 267-279.

Salman, A. B., Nossair, L. M. and El Kholy, D. M. (1995): Contribution to the radioactivity of Gabal Homrat El Girigab, Esh El Melaha range, North Eastern Desert, Egypt. Ann. Geol. Surv. Egypt, XX: 725-743.

Stern, R. J. (1994): Arc assembly and continental collision in the Neoproterozoic East African Orogen: implications for consolidation of Gondwanaland. Ann. Rev. Earth Planet. Sci., 22: 319-351.

Stern, R. J. (2002): Crustal evolution in the East African Orogen: a neodymium isotopic perspective. J. Afr. Earth Sci., 34:109-117.

Stern, R. J. (2008): Neoproterozoic crustal growth: the solid Earth system during acritical episode of the Earth history. Gond. Res., 14: 33-50.

Stoeser, D. B. and Frost, C. D. (2006): Nd, Pb, Sr, and O isotopic characterization of Saudi Arabian Shield terranes. Chem. Geol., 226: 163-188.

Streckeisean, L. and Le Maitrer, W. (1979): A chemical approximation to the modal QAPF classification of the igneous rocks. Neues Jahrbuch fur Mineralogie Abhandlungen, 136: 169-206.

Sylvester, P. J. (1989): Post-collisional alkaline granites. J. Geol., 97: 261-280.

Taylor, S. R. and McLennan, S. M., (1985): The Continental Crust: Its Composition and Evolution. Blackwell Scientific, Oxford, 312 


\section{Petrogenesis of Homrat El-Girigab alkali-feldspar granites}

Watson, E. B., and Harrison, T. M. (1983): Zircon saturation revisited: Temperature and composition effects in a variety of crustal magma types: Earth Planet. Sci. Lett., 64: 295-304.

Wetait, M. A., Mehanna, A. M., Nossair, L. M., Mhamed, A. A. W., El Balakasy, S. S., and Abdel-Hadi, A. M. (2014): Geology, geochemistry and radioactivity of Jabal Homrat El Jirjab, Esh El Melaha range, North Eastern Desert, Egypt. Nucl. Sci. Scient. J., 3: 85-106.

Whalen, J. B., Currie, K. I. and Chappell, B. W. (1987): A-type granites: geochemical characteristic, discrimination and petrogenesis. Contrib. Mineral. Petrol., 95: 407-419.

Winkler, H. G. F., Boese, M. and Marcopoulos, T. (1975): Low temperature granite melts. Neues Jahrb. Mineral. Monatsh., 6: 245-268.

Wones, D. and Eugster, H. (1965): Stability of Biotite: Experiment, Theory, and Application. Amer. Mineral., 50 (9): 1228-1272

Yang, X. M. (2017): Estimation of crystallization pressure of granite intrusions. Lithos (286-287): 324329. 
Elwan, W.

\section{نشأة جرانيتات الفلسبار القلى بمنطقه حمرة الجرجاب - شمالي الصحراء الثرقية - مصر \\ وحيد علوان \\ قسم الجيولوجيا - كلية العلوم - جامعة الزقازيق - الزقازيق- 919 ـ - الشرقية - مصر}

تقع منطقة حمرة الجرجاب في شمالي الصحراء الشرقية والذى يتميز بانتشار المتداخلات الجرانيتيه الكالس- قليه والقليه

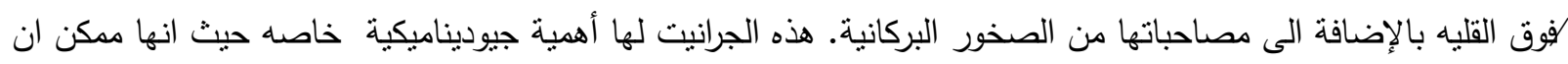
تمدنا بمعرفه عن كيفية تكون القشرة القارية للارع العربى النوبى ـ منطقة حمرة الجرجاب مغطاة ببركانيات الدخان (انديزيت و

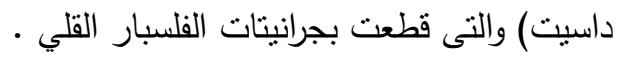

تشير كيمبائية معدن البيوتيت الى ان جرانيتات الفلسبار القلى قد تبلرت من ماجما قليه وذلك تحت ظروف أكسدة وقد نبلرت

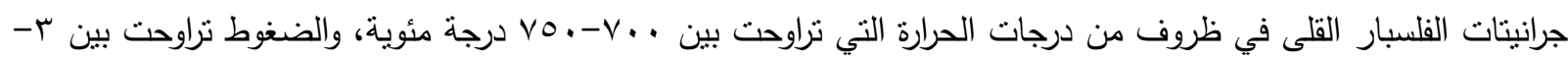

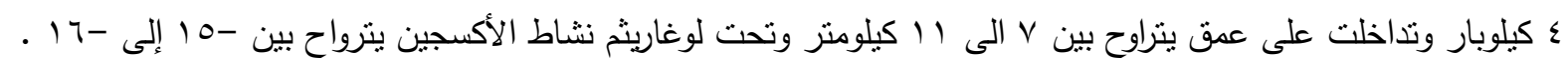
جرانيتات الفلسبار القلى بحمرة الجرجاب هي صخور قليه غنية بالحديد وقد تكونت في بيئه لا اوروجينية أو تباعديه من

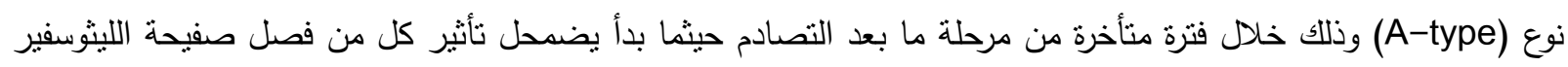

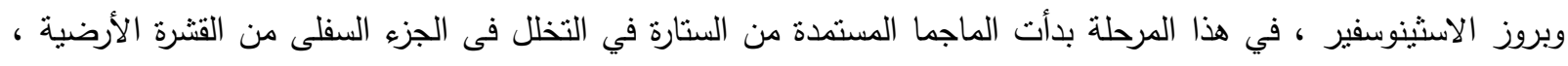

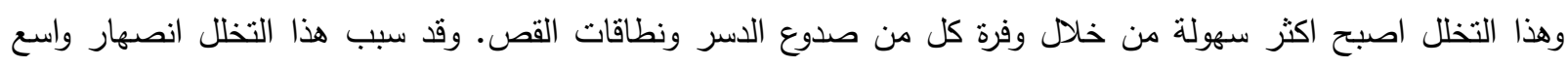
منتجا الصهير القلي التي كونت جرانيتات حمرة الجرجاب. وقد نشأت الجرانيتات تحت الدراسه من مصدر امفيبوليتى التركيب في الجزء السفلى من القترة وقد تطورت هذه الجرانيتات غالبا عن طريق التبلر التجزيئي. 